O.P. Kuznetsova, E.A. Umaev

\title{
FIGHTING POVERTY DURING THE GLOBAL ECONOMIC CRISIS (BASED ON FRANCE EXAMPLE)
}

\author{
О.П. Кузнецова, Е.А. Юмаев \\ БОРЬБА С БЕДНОСТЬЮ \\ В УСЛОВИЯХ МИРОВОГО ЭКОНОМИЧЕСКОГО КРИЗИСА \\ (НА ПРИМЕРЕ ФРАНЦИИ)
}

\begin{abstract}
Decades of the economic prosperity for many countries, including the most developed ones, have been replaced with a perceived decline in GDP and in the standard of living of the population accustomed to a certain lifestyle. Growing poverty caused social unrest, increasing the protest mood of the population. Together with the worsening aggressive foreign policy of a number of countries, primarily the United States and Great Britain, uncontrolled progression of events in this area represents a real threat to the national and economic security of many countries. Most governments of the world need to find measures of the regulatory impact on population's poverty. It is necessary to ensure not only their social efficiency, but also economic one. Extended experience gained in this field in France, traditionally has been focused on internal politics in working out redistributive mechanisms to avoid an excessive income gap between citizens. March, 32015 is the date when there was presented a new government program aimed at reducing poverty. Ambitious plans of the French government caused a huge public outcry in France and abroad, and turned out to be in the spotlight. The study of the proposed mechanisms does not allow us to evaluate the proposed plan to fight poverty only positively. However, the French experience, presented in this study, may be useful for government agencies, who develop and implement programs in this area, as well as for scientists and other experts. The analysis of existing problems and the presented overview of the proposed solutions is an impulse for further research in this area.

POVERTY; FIGHTING POVERTY; UNEMPLOYMENT; GLOBAL ECONOMIC CRISIS; FRANCE.
\end{abstract}

Десятилетия экономического процветания многих стран мира, в том числе самых развитых, сменились ощутимым снижением объемов ВВП и уровня жизни населения, привыкшего к определенному образу жизни. Рост бедности вызвал нарастание социальной напряженности, усиление протестного настроения со стороны граждан. В совокупности с обострением агрессивности внешней политики ряда государств, прежде всего США и Великобритании, неконтролируемое развитие событий в этой области представляет реальную угрозу национальной и экономической безопасности многих стран. Правительства большинства стран мира нуждаются в поиске мер регулирующего воздействия на уровень бедности населения. Необходимо обеспечить не только их социальную эффективность, но и экономическую. Богатый опыт в этой области накоплен во Франции, традиционно ориентированной во внутренней политике на выработку перераспределительных механизмов с целью устранения чрезмерного разрыва в доходах граждан. 3 марта 2015 г. была представлена новая государственная программа, направленная на снижение бедности. Амбициозные планы французского правительства вызвали широкий общественный резонанс во Франции и за ее пределами, оказались в центре обсуждения. Исследование предложенных механизмов не позволяет однозначно оценить предлагаемый план борьбы с бедностью только положительно. Вместе с тем французский опыт, емко изложенный в настоящем исследовании, может быть полезен для органов государственной власти, разрабатывающих и реализующих программы в этой области, а также ученым и иным профильным специалистам. Анализ существующих проблем и представленный обзор предложенных решений представляют собой импульс для дальнейших исследований в этой области.

БЕДНОСТЬ; БОРЬБА С БЕДНОСТЬЮ; БЕЗРАБОТИЦА; МИРОВОЙ ЭКОНОМИЧЕСКИЙ КРИЗИС; ФРАНЦИЯ.

Introduction. After the global financial and economic crisis had broken out in the so-called «developed» countries in 2008, it abruptly led to increased poverty. France has been one of the most developed countries in the world over the past 30 years from the 1980s., its welfare has been continuously growing. The trend has significantly changed with the global financial 
and economic crisis in 2008 [39, p. 94]. Researchers and experts ask: what are the longterm social and economic consequences of this process? The main problem for the government became an unemployment surge. According to Eurostat, there were 24,850,000 unemployed in the European Union in July 2014 [14].

During the crisis and shrinking resources, unemployment - the main «engine» of poverty - becomes long-term [36]. In March 2015 the total number of the unemployed in France reached 5.2 million people. However, this number was determined with the method different from the method used by Eurostat specialists. What was taken into account is the unemployed of category A (a complete lack of work), B and C categories (part-time work, temporary work). If to consider citizens enrolled in educational programs, those who will soon enter the labor market, the total number of the unemployed is even higher -5.9 million people on the mainland France territory [18]. In October 2014 2,000,000 French people lived on the amount of less than 651 euros per month, 3.6 million French people had constant problems with housing, 3.5 million people received food support [21]. At that time, the poverty threshold was set at 987 euros per month [33].

France tends to share «visible» poverty (people who are homeless and sleep on streets or in their cars, rummage through trash cans) and «invisible» (people who are unable to survive without food supply, and those who are forced to choose between food and heat, and those who are forced to spend the majority of their income on medicine and treatment) [31].

March 3, 2015 in Paris, French Prime Minister Manuel Valls presented a new ambitious government plan to reduce poverty.

The aim of the research is to study the regulatory impact of public authorities in France on the poverty level in the crisis and post-crisis development.

The object of the study is the policy of the French government, aimed at reducing poverty. The subject of the problem is declining living standards and the increasing poverty among the French population, as well as more active involvement of French citizens with incomes below the low-income poverty threshold in work and social activities.
Methods. During the study the authors used texts of programs, press releases, official statement posted on the website of France's state authorities: the official portal of the French Prime Minister, the portal for French citizens of e-public services, the Ministry of Social Welfare, Health and Women's Rights (Ministère des Affaires sociales, de la Santé et des Droits des femmes), General Welfare Inspectorate (Inspection Générale des Affaires Sociales), the Bank of France (La Banque de France), the Senate (Sénat),

Scientific articles and statistical reports of INSEE employees (Institut national de la statistique et des etudes économiques) allowed to specify the current trends and expand the idea of the phenomenon under study.

We studied materials of the French national news agencies: «Atlantico», «France Info».

The comparison of different points of view, the analysis of strengths and weaknesses of new anti-poverty program materials was made due to the contribution of the largest national media in France: «Le Monde», «Les Échos», «Le Figaro», «Libération», «Le Parisien», «Alternatives Economiques», «Radio France International», «L'Express».

All French-speaking primary sources were translated by authors themselves.

Results. Total instability caused by the ongoing global economic crisis, the decline in living standards of the population as a whole, rising unemployment forced the French government to take measures to fight the poverty rate, which declined steadily from 1996 to 2004, and then until March 2015, the time of this article preparation, the steady increase also became marked [37]. Since 2004, the annual increase in the number of French citizens living below the poverty line was: for the period from 2004 to 2010 the number had increased to 1,235 thousand people, reaching 8,617,000 [28]. However, as the experts of the European Commission noticed, with the onset of the crisis in France, there is a decrease in the level of differentiation of citizens' incomes [3], which can be explained by active redistributive policies of the country government.

Facing the economic and social crisis has a negative impact on the French society; poverty reduction plan materializes the nation efforts to help everyone to improve their living conditions. 
The aim is to strengthen equality and fraternity of the republic and social cohesion [26]. At the highest level the French government emphasizes that in coming years the fight against poverty will be one of the key areas of the country's domestic policy. [9]

The most important measure of the program to fight poverty will be the «Premium activities» (prime d'activité) [19]. It will replace the currently existing mechanism to support people who are regarded as the category of the poor, called «Solidarity labor payment» (Le Revenu de solidarité active - Le RSA). Le RSA gives people with no income or insufficient incomes guarantees of the minimum income (taking into account the household structure) [32] and other social payments. Earlier, the French government had developed methodology that allows taking into account different life situations. They established clear criteria for those who can be qualified for payment. Particular attention was paid to single citizens (parent isolé), who include unmarried, divorced, living separately, widows and widowers who have one or more dependent children or pregnant women [5]. They were guaranteed an increased level of «Solidarity labor payments».

From January 1, 2016 poor workers (les travailleurs pauvres) can supplement their earnings with the «Premium activities». This monthly social assistance, the amount of which will depend on the personal income, according to the Prime Minister Manuel Valls words, will support both the purchasing power of citizens with low incomes and encourage them to work harder. In contrast to the pre-existing support systems, it will include young people, who enter the labor market for the first time, and they are forced to sign dubious employment contracts that violate their rights [19]. The key difference of the «Premium activities» from «Solidarity labor payments» is that they involve not only social welfare payment, but wage supplements to the minimum, hereby requiring additional support and will have a strong incentive to find a job. In this case, inadequate remuneration will no longer be a stratification factor of the French society. According to the Prime Minister of France, after the introduction of new rules for receiving social assistance from the state there will be 8 million applicants (against 7 million at present) [34].
The size of the «Premium activities» is discussed in the French Parliament. According to preliminary estimates, the maximum payment should reach 215 euros per month. However, a group of associations for the fight against poverty «Alarm» (Alerte) insists on increasing the upper limit up to 250 euros [34].

A still debatable issue is which of young people aged from 18 to 25 years old will be able to qualify for the «Premium activities.» According to the report of one of the developers of the draft law, the program will benefit 300,000 young people. However, the government intends to review its approach if a young Frenchman (Frenchwoman) lives with their parents, there should be evaluated not only the personal income of the applicant, but also the overall level of the household income. In this case, the number of beneficiaries will be reduced to 200,000 people. [7]

A total of from 4 to 5 million French people earning less than 1,400 euros per month will be recipients of the «Premium activities». The French government also promises to simplify the rules for obtaining the «Premium activities» in comparison with the pre-existing procedure of the «Solidarity labor payments» registration, which, due to the complexity of administrative procedures, left one third of eligible citizens out from the program of social guarantees. The roadmap of the new program includes 48 specific measures, which are aimed primarily at helping single-parent families and citizens being unemployed for a long period of time.

2 billion euros are allocated additionally for the program. These resources will enable the government to fulfill all additional commitments, in particular, to increase the amount of «Solidarity labor payments» by $10 \%$. It is valid until December 31, 2015. On the other hand, it will introduce a new principle of life in the implementation of the social policy in France: support [26].

One more innovation will be the appearance of the activity «La généralisation du tiers payant», aimed to facilitate access to medical care. The above said innovation has caused a storm of protest and strikes among French health workers [see. E.g, 2; 4], because «tiers payant» - is a way of social security, which allows citizens not to incur any costs connected with obtaining medical, pharmaceutical services and hospital services, 
other than a «pass on visiting a specialist» (le ticket modérateur) [38]. That is, if a citizen does not ask for help in health care, in fact, now he has no mandatory medical expenses to be borne. The «Pass on visiting a specialist» implies partial compensation of expenses incurred by a citizen for a doctor's visit by the insurance company (l'Assurance Maladie). For example, a single doctor's consultation costs 22 euros, the insurer will return the citizen $70 \%$ (15.4 euros) of this amount, but keeps a 1 euro fixed fee. The total compensation amounts to 14.4 euros [20]. The size of the refund may vary depending on various factors.

In general, the health care reform, which is expected to increase the availability of health services for the population, significantly restricts the rights of health workers themselves, as well as the ability to earn. This led to strikes and dozens of thousands of people - mostly health workers - took to the streets of Paris to protest on 15 March 2015 [13]. French citizens are particularly concerned about strikes of Emergency Medical service Providers [25].

In March 2015 every seventh French household «is living» below the poverty line; one in five children is at risk due to the situation of poverty. Among people who are in a difficult situation, a high proportion work for low wages. This refers especially to women who are single parents: every third woman has the income below the lowincome poverty threshold (less than 960 euros per month) [26]. A significant number of French people suffer serious difficulties at the end of every month. Citizens living alone among the poor feel humiliated and are worried that their children will never be able to defeat poverty. According to UNICEF, by 2012 compared to 2008 , the number of poor children in France increased by 440 thousand [24]. The total number of French children living below the poverty line is up to 3 million [27]. These children are poorly nourished, they do not have the opportunity to play sports and get additional development in cultural institutions. The decline resulting from the impact of the crisis, provokes a long downward trend for them [27]. As a result, every year 150 thousand students graduate from school without a diploma. UNICEF Employees dealing with the in-depth study of the social policy, have come to a depressing conclusion that France, as well as other «developed» countries are not economically interested in helping children and young people to overcome difficult life situations [27].

We can not say that the situation is complicated only in France. In many «developed» countries, the level of child poverty has dramatically increased. According to scholars, the growth of child poverty is caused by negative manifestations of the global financial and economic crisis [11]. Recent studies show that in some developed countries, including France, governments are not able to solve the child poverty problem. 41 richest countries have 76.5 million children in poverty. This growth is explained by the constant degradation of family relations, primarily due to job loss or illconsidered actions of the authorities. The situation is particularly difficult in Greece: in the period from 2008 to 2012 child poverty has tripled [11]. However, 18 out of 41 «developed» countries and governments find means to withstand the crisis, which leads to child poverty reduction. This occurs in Chile, Finland, Norway, Poland, Slovakia. According to foreign researchers, it proves the existence of effective mechanisms. The priority for other coiuntries is to be active in searching for and implementing such mechanisms. The problem of young people is also considered in this perspective: in the European Union 7.5 million young people (which is comparable with the Swiss population) aged from 15 to 24 years old never study and never work. From 2008 to 2014 their number increased by 1 million people [11].

Obviously, not only children and adolescents are exposed to poverty. The root cause is a decrease in the income of their parents or custodial parents. With the onset of the global financial and economic crisis, the general trend of poverty in France grabs more and more attention to this issue. Thus, in three years from 2008 to 2011 the total number of people to become «poor» was 900 thousand people. The total number of people with incomes below the subsistence level was in $2011-8.7$ million people (14.3\% of the population) [1]. Poverty threshold in the period amounted to 977 euros per month.

The dynamics of poverty in France is due to three factors: labor market (unemployment); family structure (number of divorces); migration (migration which increases the share of the poor) [1]. The poorest residents of France are migrants and refugees from southern Sahara, Maghreb, 
Eastern Europe [31]. They are not necessarily citizens, but their number from year to year, as well as problems related to them increase. With the low-income poverty threshold of 977 euros per month, they often live on 166 euros per month.

What is important is an active life position of a person below the poverty line: there are studies which prove that if a person takes active measures, a period of poverty reduction does not last longer than 3 years. There are two basic «channels» to overcome poverty: family support and employment [1].

The established system of redistribution is actively criticized by fellow citizens [26], they consider it is necessary for the French government to conduct a more active policy in fighting poverty.

A major concern is the problem of the homeless: the global economic crisis, falling incomes, a significant portion of the population has difficulties renting property. Despite the creation of social housing units, in 2012 102,728 , and in $2013-117,065$ units of social housing, the deficit remains significant. The new plan offered to introduce annually no less than 150,000 units of social housing. The main difficulty is that not all social housing in France is constant [24]. A disadvantage of the «control by thermometer» (la gestion au thermomètre) is the annual spring eviction of 11-13 thousand households involving law enforcement bodies[29]. With cold weather the authorities of French departments provide homeless with social housing [35]. However, at the end of winter when the temperature is high, they are trying to evict people on the street.

Management of the social system in France is too complicated, and generates social exclusion of many citizens, as well as useless and/or excessive costs [8]. The government's plan to fight poverty aims to simplify many aspects.

According to experts, the central element of the state social management system in France should be departments (the territory of mainland France is composed of 22 regions, which are divided into 96 departments - added by the Authors). Accordingly, it is necessary to reconsider their role in the economic and social development of France, to define the boundaries of their responsibility, to add them powers [15]. However, before starting a new public administration reform, experts believe, it is important to find answers to the following questions [15]:

- Identify sources of the compensation for the new responsibilities of the departments;

- Find a balance between the social policies at the national level and social policy at the local level;

- Eliminate duplicate reference (avoiding situations where various authorities/departments send each other orders, trying to pass the buck for some work).

Rising unemployment in France in the context of the global financial and economic crisis has hit particularly hard poor citizens and citizens with low qualifications. The level of youth unemployment in the third quarter of 2014 was $23.7 \%$ [24], which forces the government to develop urgent measures to facilitate the return of lost jobs. After the current President Francois Hollande (François Hollande) came to power, the instability in the French society is growing ominously: number of unemployed has reached the unprecedented magnitude - more than 600 thousand people in March 2015. In spite of all the authorities' efforts, the unemployment has had a steady growth since 2012 [30].

In the global financial and economic crisis the availability of banking services for many citizens is greatly reduced. The French government pays special attention to this issue. Under a special study [16] there were identified the most vulnerable groups: recipients of social benefits; job seekers; citizens with health problems; persons with disabilities; single-parent families; young people; workers who do not have full employment contract (working part-time or temporary jobs). The risk group includes the middle class; their financial problems may be due to the possibility of personal turmoil (divorce, job loss, death, etc.). All of them have the potential to be blacklisted by banks, they are excluded from the scope of banking services (l'exclusion bancaire). The exclusion from banking services is understood as «the process by which a person gets into difficulty gaining access to banking services, he loses the ability to lead a normal everyday life» [16].

In $200931 \%$ of households was classified as poor, they have at least 1 loan. Mostly they take consumer loans in banks. Car loans do not exceed $8 \%$, mortgages $-6 \%$ [17, p. 67]. According to the sociological research, $17 \%$ of the received loans (among the poor) often or occasionally are 
not to be repaid; another $17 \%$ constantly experience such difficulties; the majority of borrowers - and they do it - try to repay the loan properly $[17$, p. 69$]$. Citizens who find themselves in difficult situations, having difficulty repaying the loan, can file a special appeal, which is considered by the Bank of France (Banque de France). Family and social economy advisers (conseillèr en économie sociale et familiale) interact with such citizens and help to develop and implement an individual approach to aid, judging by the response from higher authorities [6]. This measure has been much appreciated by French citizens, because thanks to it, for example, living alone the French do not feel alone in trouble.

In general, according to the study realized under the French Senate order, despite the impressive economic progress of the country, from 500 thousand up to 1 million citizens lack the opportunity to be integrated into the banking environment. It refers not only to the citizens recorded into the «black list» by banking institutions. Most of the potential representatives of this group voluntarily refrain from applying for the provision of services, obviously expecting failure [22]. The number of records on loans debts transferred to the Bank of France credit organizations at the moment is about 173 thousand applications, and they increase annually by about $6.5 \%$. Some borrowers who find themselves in a difficult situation, sent an appeal to the French bank. If we add to them those who do not send the applications, but have problems with the loan payment, the total number of citizens under the pressure of an excessively high level of debt will be 6 million [22]. The increase in the excessive debt within the global financial and economic crisis is a factor that seriously influences the well-being of the country's population, which is forced to refer to revolving credit services (credit revolving) and borrows money at an increasingly high interest (from 16 to $19.85 \%$ per annum). In the short term such citizens accumulate heavy debts. Unfortunately, the French legislation has not kept up with in this case, the market and the situation is not properly regulated.

Particular attention of the French society is given to a problem of elderly women who live alone. For a number of reasons the work record of women is interrupted: pregnancy, parenting, part-time employment. As a result, a lower level of income causes reduced pension. As a rule, the higher pension of an elderly spouse compensates this deficiency, but if left alone older women literally are in the situation of hopeless poverty, and because of their age and health problems they can not work in order to obtain an additional income [33].

Conclusion. The study of regulatory impact of the French public authorities on the poverty level in the crisis and post-crisis development can lead to the following conclusions:

1) France has reached such a high level of the economic development that during the ongoing global economic crisis can afford to declare its intention to allocate significant funds to support the poorest of the poor. At present the Russian Federation is hardly capable of allocating a similar amount to reduce poverty. Moreover, a more detailed study of French Government policy documents shows that the increase in the financial burden is not critical for the French budget due to targeting financial flows. This experience is useful for Russia when searching for opportunities to spend government funds more efficiently in order to fight against poverty.

2) The official documents do not answer the question how cost-effectiveness of interventions will be assessed. The stated key objectives such as respect for equality and fraternity seem to be excessively declarative.

3) In the aggravating global economic environment the number of valid reasons behind the French government to provide additional resources, the value of which is not so obvious, according to the authors, is a necessity to face retribution for the misguided immigration policy. In particular, France has actively supported the overthrow of the Gaddafi regime in Libya which restrained the flow of migrants to this country from North Africa. Unfortunately, due to rising tension in the international environment, the armed conflict in Ukraine supported by economically developed countries of Western Europe and North America, the Russian Federation was faced with a massive entry of Ukrainian citizens fleeing from the civil war horrors into the country. Hundreds of thousands of refugees is a huge number. Most of them are in dire need of social support measures from the state authorities and local governments of the Russian Federation. No doubt, this situation aggravates a difficult poverty problem in our country. In this regard, further research of French government approaches to solve the 
North Africa refugee problems - their flow swept France after the Gaddafi regime overthrow in Libya - is necessary.

4) Great attention of statesmen, authorities of France is paid to the need to solve the problem of over-indebtedness of citizens and access to banking services. However, efficient and effective measures are not proposed. On the contrary, opportunities to «connect» the poor to banking services are being looked for. It is worth noting the development of informative measures (better awareness of consumers of banking services), establishment of observers' posts, intention to develop a charter aimed at the inclusion of citizens in the use of banking services. Could this be an effective measure? The state is likely to try to increase its influence, tracking more accurately the mood of citizens by increasing the frequency of their interaction with low-level officials. These measures are insufficient. On the other hand, efforts continue to «warm up» the economy due to the higher demand. It seems that the governments of all countries, including France, forget that the 2008 crisis resulted from the very high levels of consumer goods loans, when goods/services have long been consumed, and the money for them need to be earned in the future. This problem is urgent for the Russian Federation. Due to the inadequate legislation in the country, there are a lot of firms offering «quick money.» And their services are addressed primarily to citizens who cannot get a loan in major lending institutions at the less interest (because of unfair performance to repay the loan in the past or an insufficient income). In fact, all this has a negative impact on poverty: people in need receive money at higher interest rates, and it makes them even poorer. It adds the criminal growth through collection agencies to return the loan and high interest rates. This issue definitely needs to be the focus of the Russian Federation Government, especially in the global economic crisis.

5) The opposition forces «Association for People's Movement» (L'Union pour un mouvement populaire), headed by Nicolas Sarkozy, accused the government of speculation: The Fight Poverty Plan was published 3 weeks before a new election; it promises serious preferences to the segments of population with high probability of protest voting. In this case, a realistic assessment of the taken measures can be given only by the middle of 2016, and so far loud proclaiming has been only loud statements. According to the analysis of the opposition, the ruling Socialist Party pushes France deeper into debts: time when the country may select 4 billion Euros for EU only through borrowing additional funds; poverty reduction is possible only at the expense of increasing national debts. Following the elections in March 2015 in 96 departments of mainland France, the ruling «left» party has lost half of its departments, it was the fourth defeat in elections at various levels since it came to power in 2012 [12]. This election also marked a huge success of ultraradical right party «National Front» (Le Front national), headed by Marine Le Pen [10]. Obviously, it is caused by ineffective policies pursued by the current leadership of the French Republic. It must be remembered that such a worst-case scenario in terms of growing poverty will raise the protest mood, and it is especially dangerous for the Russian Federation in the global economic crisis. This results from the historically high level of the social and economic asymmetry in the development of Russian territories, wide areas with high concentration of the poor, which is a breeding ground for loosening the political situation in different regions. In this connection it makes sense for developing training programs aimed at solving the poverty problems in lagging regions and regions that are of great geopolitical importance.

6) Attempts to improve health services accessibility for the poor in France were in fact implemented at the expense of the social and economic status of doctors and managers of health care institutions, which are pushed off from management. Such a redistribution policy caused fierce resistance from health workers and led to ambulance strikes.

7) According to the existing methods, the poor will always be in France. Whatever struggle the French government declared, poverty would not disappear. Thus, according to 2012, if the poor are considered as people whose income is less than $50 \%$ of the country's average income, the number of poor people will be at the level of 5 million; if the threshold is $60 \%$ from the national average income, the number of such people will be 8.6 million [23]. When implementing any program, there will be always people with income less than 50 or $60 \%$ of the average income in the country. It is necessary to find effective measures to enable people who are in difficult circumstances to integrate into the labor 
market. The proposed measures for citizens' surcharge on monthly earnings from the French government do not impact the efficiency of work. Wages will have a fixed rate, so the approval of the stimulus material is dubious. According to the authors, it would be correct to implement educational programs for the poor that could improve their skills and enter the labor market with more confidence. To date, it is unclear how a simple distribution of money can make all citizens work better. Let us remember the anti-crisis policy pursued by subjects of the Russian Federation and municipalities in 2008-
2010. At the time great attention was paid to training the unemployed citizens who were on the verge of poverty. The federal government supported regions with serious financial resources. In fact, experts did not consider, what professions were needed for each specific territory. Citizens were educated, but failed to apply their skills and get a job, raise their income level. As a whole, the state program did not reach the declared goals. It is necessary to consider these problems in the future when searching for effective measures to reduce poverty in the Russian Federation.

\section{REFERENCES}

1. 900000 «nouveaux pauvres» en France avec la crise: mais qui sont-ils et comment peuvent-ils s'en sortir? URL: http://www.atlantico.fr/decryptage/900-000nouveaux-pauvres-en-france-avec-crise-mais-qui-sontet-comment-peuvent-en-sortir-julien-damon-841725.htm (date de citation 12.03.2015)

2. Bartnik M. Généralisation du tiers payant: pourquoi les mйdecins sont contre URL: www.lefigaro. fr/social/2015/01/06/09010-20150106ARTFIG00297generalisation-du-tiers-payant-pourqui-ca-bloque.php (date de citation 12.03.2015)

3. Beffi M., Clerc M-É., Thévenot C. Dossier Inegalité, pauvretй et protection sociale en Europe. URL http://www.insee.fr/fr/themes/document.asp?reg_id=0 \&id=4269 (date de citation 12.03.2015).

4. Bourgneuf C. Pourquoi les médcins refusent-ils le tiers payant generalize? URL: www.liberation.fr/so ciete/2014/12/22/pourquoi-les-medecins-refusent-ils-letiers-payant-generalise_1168655 (date de citation 12.03.2015).

5. Calcul du montant du revenue de solidarité active. URL: www.vosdroits.service-public.fr/particuliers /F502.xhml\#N10165 (date de citation 12.03.2015).

6. Changement de regard sur la pauvreté et la précarité: Prévention et lutte contre le surendettement Platforme Budget CCAS Grenoble. URL: www.socialsante.gouv.fr/espaces, $770 /$ handicap-exclusion.775/dossi ers, 806/lutte-cjntre-la-pauvrete-et-pour-1,2380/conferen ce-de-decembre-2012,2389/les-film-de-la-conference, 2392/changement-de-regard-sur-la,15291.html (date de citation 12.03.2015).

7. Chastand J.-B. Comment la nouvelle prime d'activité va fonctionner. URL: www.lemonde.fr/emploi /article/2015/02/28/comment-la-nouvelle-prime-d-acti vite-va-fonctionner 4585125 1698637.html (date de citation 12.03.2015).

8. Chereque F., Vanackere S. Évaluation de la 1-ère année de mise en oeuvre du plan pluriannuel contre la pauvreté et pour l'inclusion social. URL: www.igas.gouv.fr/spip.php?article350 (date de citation 12.03.2015).

9. Communiqué de press du Premier minister pour la remise du rapport pluriannuel (janvier 2014).
URL: http://www.social-sante.gouv.fr/espaces,770/handicapexclusion,775/dossiers, 806/lutte-contre-la-pauvrete-etpour-1,2380/actualites, 2398/les-communiques-et-dossiers-de, 2400/cp-janvier-2014_remise-rapport, 16970.html (date de citation 12.03.2015).

10. Ficek I. Le FN butte toujours sur un plafond de verre... qui monte. URL: http://www.lesechos.fr/poli tique-societe/politique/0204265974239-le-fn-butte-toujo urs-sur-un-plafond-de-verre-qui-monte-1106792.php (date de citation 30.03.2015).

11. France: 440.000 enfants de plus touchés par la pauvreté, selon l'Unicef. URL: http://www.leparisien. fr/economie/la-crise-economique-affecte-les-enfants-des -pays-riches-28-10-2014-4247797.php\#xtref $=$ https\%3A\% 2F\%2Fwww.google.ru\%2F (date de citation 12.03.2015).

12. Freyssenet E. Départementales: l'exécutif subit sa quatrième défaite depuis 2012. URL: http://www.lese chos.fr/politique-societe/politique/0204263566341-depar tementales-lexecutif-subit-sa-quatrieme-defaite-depuis2012-1106430.php (date de citation 30.03.2015).

13. Godeluck S. Les médecins fourbissent leurs armes avant la manifestation de dimanche. URL: http://www. lesechos.fr/economie-france/social/0204222026653-lesmedecins-fourbissent-leurs-armes-avant-la-manifestation -de-dimanche-1101507.php (date de citation 16.03.2015).

14. Gradt J.-M. L'Europe comptait près de 25 millions de chômeurs en juillet. URL: http://www.lese chos.fr/29/08/2014/lesechos.fr/0203733870379 1-europecomptait-pres-de-25-millions-de-chomeurs-en-juillet.htm (date de citation 12.03.2015).

15. Groupe de travail «Gouvernance des politiques de solidarité». URL: http://www.social-sante.gouv.fr/ IMG/pdf/Rapport_gouvernance_final_couv.pdf (date de citation 12.03.2015).

16. Groupe de travail «Inclusion bancaire et lutte contre le surendettement». URL: http://www.socialsante.gouv.fr/IMG/pdf/Rapport_de_Monsieur_Franco is_Soulage_-_acces_aux_services_bancaires_et_lutte_co ntre le surendettement.pdf (date de citation 12.03.2015).

17. Jauneau P., Olm Ch. Les conditions d'accès aux services bancaires des ménages vivant sous le seuil de pauvreté. URL: http://www.banque-france.fr/ccsf/ 
fr/telechar/publications/rapport credoc etude conditi ons_acces_services_bancaires_pauvrete.pdf (date de citation 12.03.2015).

18. Jeanneau L., Hyvert F. Le chômage de longue durn̆e, une fatalité? // Alternatives Economiques. 2015. mars. № 344. URL: http://www.alternatives-economi ques.fr/le-chomage-de-longue-duree--une-fat_fr_art_1 351_71856.html (date de citation 12.03.2015).

19. Journal en français facile du 03/03/2015. URL: http://www.rfi.fr/emission/20150303-journal-fran cais-facile-03032015-21h00-21h10-tu/ (date de citation 12.03.2015).

20. Karel F. Le ticket moderateur: Définition et règles de fonctionnement. URL: www.news-assurances. com/actualites/le-ticket-moderateur-definition-et-reglesde-fonctionnement/016710384 (date de citation 12.03.2015).

21. La grande pauvreté persiste en France. URL: http://www.inegalites.fr/spip.php?article1648 (date de citation 12.03.2015).

22. La lutte contre la pauvreté et l'exclusion: une responsabilité a partager. URL: http://www.senat.fr/rap/ r07-445-1/r07-445-122.html (date de citation 12.03.2015).

23. La pauvreté progresse en France. URL: http:// www.inegalites.fr/spip.php?article270 (date de citation 12.03.2015).

24. Lescoffit M., Deplanque H. Les politiques démunies face a la pauvreté. URL: http://www.libera tion.fr/politiques/2015/01/28/les-politiques-publiquesdemunies-face-a-la-pauvrete 1190826 (date de citation 12.03.2015).

25. Loi santé: Marisol Touraine va recevoir les médecins en colère. URL: www.franceinfo.fr/actu/ societe/article/les-medecins-envahissent-les-rues-de-pa ris-pour-protester-contre-la-loi-de-sante-656757 (date de citation 19.03.2015).

26. Lutte contre la pauvreté: «Le défi a relever est la sauvegarde de notre modèle social et des valeurs qui le portent». URL: http://www.gouvernement.fr/luttecontre-la-pauvrete-le-defi-a-relever-est-la-sauvegarde-de -notre-modele-social-et-des-valeurs (date de citation 12.03.2015).

27. Nedelec G. Crise économique: 2,6 millions de nouveaux enfants pauvres dans les pays riches. URL: http://www.lesechos.fr/28/10/2014/lesechos.fr/0203892 067835_crise-economique---2-6-millions-de-nouveaux -enfants-pauvres-dans-les-pays-riches.htm (date de citation 12.03.2015).

28. Nombre de personnes pauvres. URL: http:// www.insee. $\mathrm{fr} / \mathrm{fr} /$ themes/series-longues.asp?indicateur $=\mathrm{nb}$ -personnes-pauvres (date de citation 12.03.2015).

29. Overhoff N. Arrktons la gestion au thermometer! // Alternatives Economiques. 2014. mai. № 335. URL: www.alternatives-economiques.fr/arre tons-la-gestion-au-thermometre_fr_art_1298_68152.html (date de citation 12.03.2015).

30. Plan de lutte contre la pauvreté: le Gouvernement distribue de nouvelles aides, sans toutefois s'assurer de son financement. URL: http:// www.u-mp.org/actualites/a-la-une/plan-de-lutte-contre-la-pauvre te-le-gouvernement-distribue-de-11610303 (date de citation 12.03.2015).

31. Politi C. Qui sont les nouveaux pauvres en France? URL: http://www.lexpress.fr/actualite/societe/ qui-sont-les-nouveaux-pauvres-en-france_1617888.html (date de citation 12.03.2015).

32. Revenu de solidarité active. URL: www.vosd roits.service-public.fr/particuliers/N19775.xhtml (date de citation 12.03.2015)

33. Rollot C. Les seniors de plus en plus touchés par la pauvreté. URL: http://www.lemonde.fr/societe/ article/2014/11/06/les-seniors-de-plus-en-plus-touchespar-la-pauvrete 4518935 3224.html (date de citation 12.03.2015).

34. Russell G. Lutte contre la pauvreté: tout savoir sur la nouvelle prime d'activité. URL: http://www.lefiga ro.fr/emploi/2015/03/03/09005-20150303ARTFIG00009 -tout-savoir-sur-la-nouvelle-prime-d-activite.php (date de citation 12.03.2015).

35. Sans-abri: «Nous demandons la fin de la gestion au thermometer» (Florent Gueguen). URL: www.franceinfo.fr/actu/societe/article/florent-gueguennous-demandons-la-fin-de-la-gestion-au-thermometrede-1-hebergement-des-sans-abri-624587 (date de citation 12.03.2015).

36. Saglio P. Crise et pauvreté // Alternatives Economiques. 2008. décembre. № 275. URL: http://www. alternatives-economiques.fr/crise-et-pauvrete fr art 801 40897.html (date de citation 12.03.2015).

37. Taux de pauvreté. URL: http://www.insee. $\mathrm{fr} / \mathrm{fr} /$ themes/series-longues.asp?indicateur=taux-pauvrete (date de citation 12.03.2015).

38. Tiers payant. URL: www.larousse.fr/dictionnaires /francais/tiers/78041/locution?q=payant \#167152 (date de citation 12.03.2015).

39. Trente ans de vie économique et sociale. Йdition 2014. URL: http://www.insee.fr/fr/publicationset-services/sommaire.asp?ref id=HISTO14 (date de citation 30.03.2015).

\section{СПИСОК ЛИТЕРАТУРЫ}

1. 900000 «nouveaux pauvres» en France avec la crise: mais qui sont-ils et comment peuvent-ils s'en sortir? URL: http://www.atlantico.fr/decryptage/900-000nouveaux-pauvres-en-france-avec-crise-mais-qui-sontet-comment-peuvent-en-sortir-julien-damon-841725.html (date de citation 12.03.2015)

2. Bartnik M. Généralisation du tiers payant: pourquoi les mŭdecins sont contre URL: www.lefigaro.
fr/social/2015/01/06/09010-20150106ARTFIG00297generalisation-du-tiers-payant-pourqui-ca-bloque.php (date de citation 12.03.2015).

3. Beffi M., Clerc M-É., Thévenot C. Dossier Inegalité, pauvretй et protection sociale en Europe. URL: http://www.insee.fr/fr/themes/document.asp?reg_id=0 \&id=4269 (date de citation 12.03.2015).

4. Bourgneuf C. Pourquoi les médcins refusent-ils 
le tiers payant generalize? URL: www.liberation.fr/so ciete/2014/12/22/pourquoi-les-medecins-refusent-ils-letiers-payant-generalise_1168655 (date de citation 12.03.2015).

5. Calcul du montant du revenue de solidarité active. URL: www.vosdroits.service-public.fr/particuliers /F502.xhml\#N10165 (date de citation 12.03.2015).

6. Changement de regard sur la pauvreté et la précarité: Prévention et lutte contre le surendettement Platforme Budget CCAS Grenoble. URL: www.socialsante.gouv.fr/espaces, $770 /$ handicap-exclusion.775/dossi ers, 806/lutte-cjntre-la-pauvrete-et-pour-1,2380/conferen ce-de-decembre-2012,2389/les-film-de-la-conference, 2392/changement-de-regard-sur-la,15291.html (date de citation 12.03.2015).

7. Chastand J.-B. Comment la nouvelle prime d'activité va fonctionner. URL: www.lemonde.fr/emploi /article/2015/02/28/comment-la-nouvelle-prime-d-acti vite-va-fonctionner_4585125_1698637.html (date de citation 12.03.2015).

8. Chereque F., Vanackere S. Évaluation de la 1-ère année de mise en oeuvre du plan pluriannuel contre la pauvreté et pour l'inclusion social. URL: www.igas.gouv.fr/spip.php?article350 (date de citation 12.03.2015).

9. Communiqué de press du Premier minister pour la remise du rapport pluriannuel (janvier 2014) URL: http://www.social-sante.gouv.fr/espaces,770/handicapexclusion,775/dossiers, 806/lutte-contre-la-pauvrete-etpour-1,2380/actualites,2398/les-communiques-et-dossiers-de, 2400/cp-janvier-2014_remise-rapport, 16970.html (date de citation 12.03.2015).

10. Ficek I. Le FN butte toujours sur un plafond de verre... qui monte. URL: http://www.lesechos.fr/poli tique-societe/politique/0204265974239-le-fn-butte-toujo urs-sur-un-plafond-de-verre-qui-monte-1106792.php (date de citation 30.03.2015).

11. France: 440.000 enfants de plus touchés par la pauvreté, selon l'Unicef. URL: http://www.leparisien. fr/economie/la-crise-economique-affecte-les-enfants-des -pays-riches-28-10-2014-4247797.php\#xtref=https\%3A\% 2F\%2Fwww.google.ru\%2F (date de citation 12.03.2015).

12. Freyssenet E. Départementales: l'exécutif subit sa quatrième défaite depuis 2012. URL: http://www.lese chos.fr/politique-societe/politique/0204263566341-depar tementales-lexecutif-subit-sa-quatrieme-defaite-depuis2012-1106430.php (date de citation 30.03.2015).

13. Godeluck S. Les médecins fourbissent leurs armes avant la manifestation de dimanche. URL: http://www. lesechos.fr/economie-france/social/0204222026653-lesmedecins-fourbissent-leurs-armes-avant-la-manifestation -de-dimanche-1101507.php (date de citation 16.03.2015).

14. Gradt J.-M. L'Europe comptait près de 25 millions de chômeurs en juillet. URL: http://www.lese chos.fr/29/08/2014/lesechos.fr/0203733870379 1-europecomptait-pres-de-25-millions-de-chomeurs-en-juillet.htm (date de citation 12.03.2015).

15. Groupe de travail «Gouvernance des politiques de solidarité». URL: http://www.social-sante.gouv.fr/ IMG/pdf/Rapport_gouvernance_final_couv.pdf (date de citation 12.03.2015).

16. Groupe de travail «Inclusion bancaire et lutte contre le surendettement». URL: http://www.socialsante.gouv.fr/IMG/pdf/Rapport_de_Monsieur_Franco is_Soulage_-_acces_aux_services_bancaires_et_lutte_co ntre le surendettement.pdf (date de citation 12.03.2015).

17. Jauneau P., Olm Ch. Les conditions d'accès aux services bancaires des ménages vivant sous le seuil de pauvreté. URL: http://www.banque-france.fr/ccsf/ $\mathrm{fr} /$ telechar/publications/rapport_credoc_etude_conditi ons_acces_services_bancaires_pauvrete.pdf (date de citation 12.03.2015).

18. Jeanneau L., Hyvert F. Le chômage de longue durŭe, une fatalité? // Alternatives Economiques. 2015. mars. № 344. URL: http://www.alternatives-economi ques.fr/le-chomage-de-longue-duree--une-fat_fr_art_1 351 71856.html (date de citation 12.03.2015).

19. Journal en français facile du 03/03/2015. URL: http://www.rfi.fr/emission/20150303-journal-fran cais-facile-03032015-21h00-21h10-tu/ (date de citation 12.03.2015).

20. Karel F. Le ticket moderateur: Définition et règles de fonctionnement. URL: www.news-assurances. com/actualites/le-ticket-moderateur-definition-et-reglesde-fonctionnement/016710384 (date de citation 12.03.2015).

21. La grande pauvreté persiste en France. URL: http://www.inegalites.fr/spip.php?article1648 (date de citation 12.03.2015).

22. La lutte contre la pauvreté et l'exclusion: une responsabilité a partager. URL: http://www.senat.fr/rap/ r07-445-1/r07-445-122.html (date de citation 12.03.2015).

23. La pauvreté progresse en France. URL: http:// www.inegalites.fr/spip.php?article270 (date de citation 12.03.2015).

24. Lescoffit M., Deplanque H. Les politiques démunies face a la pauvreté. URL: http://www.libera tion.fr/politiques/2015/01/28/les-politiques-publiquesdemunies-face-a-la-pauvrete_1190826 (date de citation 12.03.2015).

25. Loi santé: Marisol Touraine va recevoir les médecins en colère. URL: www.franceinfo.fr/actu/ societe/article/les-medecins-envahissent-les-rues-de-pa ris-pour-protester-contre-la-loi-de-sante-656757 (date de citation 19.03.2015).

26. Lutte contre la pauvreté: «Le défi a relever est la sauvegarde de notre modèle social et des valeurs qui le portent». URL: http://www.gouvernement.fr/luttecontre-la-pauvrete-le-defi-a-relever-est-la-sauvegarde-de -notre-modele-social-et-des-valeurs (date de citation 12.03.2015).

27. Nedelec G. Crise économique: 2,6 millions de nouveaux enfants pauvres dans les pays riches. URL: http://www.lesechos.fr/28/10/2014/lesechos.fr/0203892 067835_crise-economique---2-6-millions-de-nouveaux -enfants-pauvres-dans-les-pays-riches.htm (date de citation 12.03.2015).

28. Nombre de personnes pauvres. URL: http:// www.insee.fr/fr/themes/series-longues.asp?indicateur $=\mathrm{nb}$ -personnes-pauvres (date de citation 12.03.2015). 
29. Overhoff N. Arrktons la gestion au thermometer! // Alternatives Economiques. 2014. mai. № 335. URL: www.alternatives-economiques.fr/arre tons-la-gestion-au-thermometre_fr_art_1298_68152.html (date de citation 12.03.2015).

30. Plan de lutte contre la pauvreté: le Gouvernement distribue de nouvelles aides, sans toutefois s'assurer de son financement. URL: http:// www.u-mp.org/actualites/a-la-une/plan-de-lutte-contre-la-pauvre te-le-gouvernement-distribue-de-11610303 (date de citation 12.03.2015).

31. Politi C. Qui sont les nouveaux pauvres en France? URL: http://www.lexpress.fr/actualite/societe/ qui-sont-les-nouveaux-pauvres-en-france_1617888.html (date de citation 12.03.2015).

32. Revenu de solidarité active. URL: www.vosd roits.service-public.fr/particuliers/N19775.xhtml (date de citation 12.03.2015).

33. Rollot C. Les seniors de plus en plus touchés par la pauvreté. URL: http://www.lemonde.fr/societe/ article/2014/11/06/les-seniors-de-plus-en-plus-touchespar-la-pauvrete_4518935_3224.html (date de citation 12.03.2015).

34. Russell G. Lutte contre la pauvreté: tout savoir sur la nouvelle prime d'activité. URL: http://www.lefiga ro.fr/emploi/2015/03/03/09005-20150303ARTFIG00009 -tout-savoir-sur-la-nouvelle-prime-d-activite.php (date de citation 12.03.2015).

35. Sans-abri: «Nous demandons la fin de la gestion au thermometer» (Florent Gueguen). URL: www.franceinfo.fr/actu/societe/article/florent-gueguennous-demandons-la-fin-de-la-gestion-au-thermometrede-1-hebergement-des-sans-abri-624587 (date de citation 12.03.2015).

36. Saglio P. Crise et pauvreté // Alternatives Economiques. 2008. décembre. № 275. URL: http://www. alternatives-economiques.fr/crise-et-pauvrete_fr_art_801 _40897.html (date de citation 12.03.2015).

37. Taux de pauvreté. URL: http://www.insee. $\mathrm{fr} / \mathrm{fr} /$ themes/series-longues.asp?indicateur=taux-pauvrete (date de citation 12.03.2015).

38. Tiers payant. URL: www.larousse.fr/dictionnaires /francais/tiers/78041/locution?q=payant\#167152 (date de citation 12.03.2015).

39. Trente ans de vie économique et sociale. Йdition 2014. URL: http://www.insee.fr/fr/publicationset-services/sommaire.asp?ref_id=HISTO14 (date de citation 30.03.2015).

KUZNETSOVA Ol'ga P. - Omsk State Technical University.

644050. Mira av. 11. Omsk. Russia. E-mail: kuznetsova@omgtu.ru

КУЗНЕЦОВА Ольга Павловна - проректор по внеучебной работе и социальным вопросам, зав. кафедрой «ГМУиТД» Омского государственного технического университета, доктор экономических наук. 644050, пр. Мира, д. 11, г. Омск, Россия. E-mail: kuznetsova@omgtu.ru

UMAEV Egor A. - Omsk State Technical University.

644050. Mira av. 11. Omsk. Russia. E-mail: egorumaev@rambler.ru

ЮМАЕВ Егор Александрович - доцент Омского государственного технического университета, кандидат экономических наук.

644050. Mira av. 11. Omsk. Russia. E-mail: egorumaev@rambler.ru 